Ірина ЯЩЕНКО,

orcid.org/0000-0001-7680-4329

аспірантка кафедри образотворчого мистецтва,

музикознавства та культурологї

Сумського державного педагогічного університету імені А. С. Макаренка

(Суми, Украӥна) irafima2020@gmail.com

\title{
ТВОРЧИЙ СПАДОК ЕСТРАДНИХ МИТЦІ СУМЩИНИ (НА ПРИКЛАДІ АРТИСТІВ-ВОКАЛІСТІВ СУМСЬКОЇ ОБЛАСНОЇ ФІЛАРМОНІї)
}

\begin{abstract}
У статті висвітлено творчу спадщуину естрадних виконавців Сумської області, серед яких заслужений артист України Леонід Матвіснко, заслужений артист Украӥни, заслужений працівник культури Украйни Свген Радченко, заслужений артист Украӥни Володимир Прихожай. Стаття також містить коротку історичну ретроспективу розвитку Сумської обласної філармонії.

Зазначається, щчо оскільки філармонії позиціонуються як провідні музичні установи в Украӥні, вони несуть значну відповідальність перед країною та суспільством. У зв 'язку з цим адміністрація та колективи філармонії, незважаючи на всі проблеми, намагаються иілеспрямовано та збалансовано розвивати всі напрями та жанри філармонії. 3 огляду на ией аспект, особлива увага приділяється досягненню високого художнього рівня власних концертних заходів, які повинні відповідати найкращим стандартам світового та європейського рівнів.

Доведено, ше основними завданнями філармонії в сучасній Україні є концертна діяльність, щзо проводиться з метою популяризації вітчизняного та зарубіжного мистецтвва, класичної спадщини, відродження української наџіональної культури, міжнародних та національних конкурсів і фестивалів, участь у наџіональних та міжнародних мистецьких проєктах, презентаціях, творчих звітах, науково-практичних конференціях, виставках, мистецьких, культурних та громадських заходах за участю глав держав та урядів.

Зроблено висновок, щзо широкий вектор творчості регіональних митиів вказує на їх плідну роботу у своїй галузі, і иее засвідчують матеріали різного спрямування: 1) конщертні афіші; 2) коментарі та відгуки, які залишають слухачі в соиіальних мережах щчодо виступу артиста; 3) документальні матеріали (звіти різноманітних обласних, районних концертних та мистецьких установ і товариств); 4) статті аналітичного характеру, які присвячені ювілейним датам виконавців і композиторів; 5) підсумкові звіти стосовно творчої діяльності культурно-мистецьких закладів та підсумкової роботи творчих колективів; б) численні публікації регіональних видань, щзо засвідчують високу професійну майстерність і статусність артистів регіону; 7) відео звіти кониертних виступів на різноманітних майданчиках; 8) ротація на радіо та телебаченні.
\end{abstract}

Ключові слова: естрадні артисти-вокалісти, Сумська обласна філармонія, В. Козупиця, Л. Матвієнко, В. Прихожай, С. Радченко, філармонійна діяльність.

Irina YASHCHENKO, orcid.org/0000-0001-7680-4329 Graduate Student at the Department of Fine Arts, Musicology and Cultural Studies Sumy State Pedagogical University named after A. S. Makarenko (Sumy,Ukraine)irafima2020@gmail.com

\section{CREATIVE HERITAGE OF POP ARTISTS OF SUMY REGION (ON THE EXAMPLE OF ARTISTS-VOCALISTS OF SUMY REGIONAL PHILHARMONIC)}

The article highlights creative heritage of pop singers of Sumy region, including Honored Artist of Ukraine Leonid Matviienko, Honored Artist of Ukraine, Honored Worker of Culture of Ukraine Yevhen Radchenko, Honored Artist of Ukraine Volodymyr Prykhozhai. The article also contains a brief historical retrospective of the Sumy Regional Philharmonic development.

It is noted that since the Philharmonic is positioned as a leading music institution in Ukraine, they have a significant responsibility to the country and society. In this regard, the Philharmonic administration and teams, despite all the problems, try to purposefully and in a balanced way to develop all areas and genres of philharmonic activities. Given this aspect, special attention is paid to achieving a high artistic level of their own concert events, which must meet the best standards of world and European level. 
It is proved that the main tasks of the Philharmonic in modern Ukraine are concert activities conducted to promote domestic and foreign art, classical heritage, revival of Ukrainian national culture, international and national competitions and festivals, participation in national and international art projects, presentations, creative reports, scientific and practical conferences, exhibitions, artistic, cultural and public events with the participation of heads of state and government.

It is concluded that the wide vector of regional artists' creativity indicates their fruitful work in their field, and this is evidenced by materials of different directions: 1) concert posters; 2) comments and feedback left by listeners on social networks regarding the artists' performance; 3) documentary materials (reports of various regional, district concert and art institutions and societies); 4) articles of an analytical nature, which are devoted to the anniversaries of performers and composers; 5) final reports on the creative activity of cultural and artistic institutions and the final work of creative teams; 6) numerous publications of regional periodicals that certify the high professionalism and status of artists in the region; 7) video reports of concert performances at various events; 8) rotation on radio and television.

Key words: pop artists-vocalists, Sumy Regional Philharmonic, V. Kozupytsia L. Matviienko, V. Prykhozhai, Ye. Radchenko, philharmonic activity.

Постановка проблеми. На сучасному етапі розвитку суспільства й за умов відродження національної культури особливого значення набуває питання виховання духовно багатої, високо культурної, творчої особистості. Відтак, особливе значення в цьому процесі має мистецтво, зокрема, музичне. Беззаперечно, що вокальна музика початку XXI століття - одна з найбільш неоднозначних і суперечливих галузей українського музичного мистецтва. Особливо відчувається диференційованість іiі на «академічну», що спирається на усталені традиції вітчизняної музики, та масову поп- і рок-культуру, художні та стильові основи яких усе більше віддаляються одні від одних.

В Україні, крім театрів опери та балету, музичної комедії та оперети, діє ще й 25 філармоній (в усіх областях України). У нашому дослідженні ми зосередили увагу на діяльність артистів-вокалістів Сумської обласної філармонії. На наш погляд, саме філармонійне мистецтво містить основний потенціал музичного професіоналізму, найвищі здобутки і найбільший морально-виховний потенціал держави.

Вважається, що основними завданнями філармоній сучасної України є концертна діяльність, що проводиться 3 метою широкої пропаганди вітчизняного й зарубіжного мистецтва, класичної спадщини, відродження української національної культури, проведення міжнародних та всеукраїнських конкурсів і фестивалів, участь у загальнодержавних та міжнародних художніх проектах, презентаціях, творчих звітах, науково-практичних конференціях, виставках, мистецько-культурних та громадських акціях за участю керівників держави та уряду.

Зауважимо, що оскільки філармонії позиціонуються як провідні музичні заклади України, на них покладається значна відповідальність перед країною і суспільством. У зв'язку з цим керівництво й колективи, незважаючи на всі проблеми, намагаються цілеспрямовано та збалансовано розвивати всі напрями й жанри філармонічної діяльності.
Ураховуючи даний аспект, особлива увага приділяється досягненню високого художнього рівня власних концертних заходів, які повинні відповідати кращим зразкам світового та європейського рівня.

На підставі зазначеного вище можемо стверджувати, що значна роль у досягненні успіху у філармонічній діяльності належить артистамвокалістам окремих регіонів, зокрема митцям Сумської області. Виходячи з аналізу мистецького простору Сумщини можна з упевненістю зазначити, що він складається з творчого доробку багатьох митців, музикантів та співаків, яка не лише створює умови для формування та розвитку мистецтва й культури, але й формує національну спільність. До провідних митців регіону відносимо артистів-вокалістів Сумської обласної філармонії.

Аналіз досліджень. У контексті дослідження вважаємо за необхідне проаналізувати наукові розвідки, присвячені проблемі концертної діяльності. Відтак, жанрова різноманітність концертної діяльності стала предметом спеціального розгляду таких теоретиків та практиків мистецтва, як Я. Бережанська, М. Грінберг, І. Зайцева, Т. Кудінова, Г. Нейгауз, М. Тараканов, А. Вайлдер, М. Еттінгер та ін. Аналізові проблеми організації концертної діяльності присвячені наукові праці О. Белоцерковського, І. Боярської, О. Левко, В. Левко, С. Морозової, М. Ржевської, О. Хомової, К. Шамаєвої та ін.

Історію та теорію естрадно-вокального мистецтва досліджували А. Бондаренко, Н. Дрожжина, С. Манько, М. Мозговий, Е. Рибакова, Т. Рябуха, Т. Самая, Т. Сідлецька, Г. Шехтман, І. Яркіна та ін.

Факти та явища музичної культури різних регіонів та міст України комплексно висвітлено в науковому доробку таких дослідників, як М. Антошко, В. Бондарчук, Т. Бурдейна-Публіка, О. Васюта, І. Глібовицький, М. Долгіх, М. Загайкевич, Л. Кияновська, А. Литвиненко, Г. Локощенко, T. Мартинюк, Т. Медведнікова, М. Ржевська, Т. Росул, І. Рябцева, О. Стебельська, О. Ущапівська, П. Шиманський, С. Щітова, О. Якимчук та ін.). 
Однак наразі системне науково-мистецтвознавче дослідження, присвячене естрадним митцям Сумщини, відсутнє, що додатково обгрунтовує актуальність дослідження, результати якого висвітлюються у даній статті.

Мета статті - охарактеризувати творчий спадок естрадних співаків Сумщини на прикладі артистів Сумської обласної філармонії.

Виклад основного матеріалу. Насамперед, наголосимо, що осередком естрадного вокального мистецтва Сумщини можна вважати Сумську обласну філармонію, яка розташована в старовинній будівлі Повітового дворянського зібрання на території колишнього саду Кондратьєвих - найбільших землевласників у Сумському повіті, до роду яких належав і засновник міста Суми Герасим Кондратьєв.

Для початку вважаємо за необхідне звернутися до історичних витоків появи й існування філармонії. Зауважимо, що в будинку вдало поєднано офіційну парадність із підкресленою розкішшю оздоблення. На першому поверсі знаходилися ресторан, музичний салон і театральний зал, у якому свого часу виступали Федір Шаляпін, Леонід Собінов, артисти Міланської опери, хор Валерія Полянського й Віктора Іконніка, ансамбль Дмитра Покровського, грав Святослав Ріхтер.

Значимим, на наш погляд, було те, що велика зала використовувалася не лише за своїм прямим призначенням - для з'їздів дворян і промисловців, а також тут відбувалися професійні й аматорські оперні спектаклі, концерти музикантів і вокалістів. За акустикою цей зал був одним із кращих.

Пам'ятним для шанувальників оперного мистецтва був 1913 рік, коли у виконанні солістів Міланської опери сумчани слухали «Травіату» Д. Верді, «Кармен» Ж. Бізе та «Джоконду» А. Понк'йоллі.

У 1916 році в приміщенні філармонії розташовувався кінотеатр «Люкс». Після 1917-го будівлю було передано під клуб ім. Т. Г. Шевченка, пізніше - клуб металістів (заводу ім. Фрунзе). А вже 31939 року в цій будівлі розмістилася Філармонія. Протягом 1945-1976 років частину приміщень займав Сумський художній музей. У 2007-2008 роках у Сумській обласній філармонії зроблено капітальний ремонт та 3 Троїцького Собору перенесено орган.

Безперечно, що сьогодні філармонія є провідним обласним закладом культури Сумщини з концертною залою на 370 посадкових місць.

Наразі колектив філармонії налічує більше 130 працівників, серед яких 90 артистів, більшість iз яких $є$ лауреатами престижних міжнародних i всеукраїнських конкурсів.
Розглядаючи представників мистецької еліти Сумщини, виділимо найвидатніших митців краю, серед яких Заслужений артист України Леонід Матвієнко, Заслужені діячі мистецтв України - Валерій Козупиця та Володимир Прихожай, Заслужений працівник культури України - Свген Радченко, співак і композитор - Олександр Гусак, Заслужений працівник культури України Тетяна Шулікова, співак і композитор Олександр Крикуненко, співаки й композитори Свген Станкевич та Тетяна Карпенко, Сімейний дует Світлана та Георгій Білоножко, співак і композитор Олег Бут, виконавець та композитор Ігор Чумак.

Проаналізуємо діяльність та творчий доробок провідних артистів-вокалістів Сумської обласної філармонії. Так, яскравою постаттю митецького простору Сумщини є Заслужений діяч мистецтв України, лауреат міжнародних конкурсів, автор і виконавець, співак і композитор, соліст Сумської обласної філармонії Валерій Олександрович Козупиця. Він народився 27 серпня 1960 року в місті Суми. 3 раннього дитинства мріяв стати співаком, і це зрозуміло, адже він виріс у творчій родині. Мама Валерія працювала в будинку культури і з раннього дитинства прививала любов до прекрасного. Саме родина композитора та спогад про щасливе дитинство надихнули його через десяток років написати пісню «А нам іще рости, рости». Вважаємо, що слухаючи цю пісню, будьякий дорослий може подумки поринути в дитинство. Невипадково ця пісня є однією з найкращих, адже звучить, як позивні до «Нової епохи», де ще стільки всього незвіданого та прекрасного.

Починаючи 3 80-х років минулого століття, В. Козупиця своєю невтомною працею та творчістю прославляє наш рідний край. Пісенна спадщина автора складає більше 100 пісень, мелодії 3 яких знають і люблять Сумчани, наприклад, пісні «Сумчанка», «Музиканти на весіллі», «Прийшло кохання» та багато інших. Композитор вважає, що для того, аби досягти успіху в будь-якій справі, а особливо в мистецтві, потрібно мати особисте кредо по життю.

«Кожна людина повинна прагнути залишити після себе на землі щось прекрасне», - впевнено стверджує композитор. I він дійсно залишає прийдешнім поколінням справжні пісенні перлини. В його піснях оспівана вся любов до рідного краю, людей.

Вслухаючись у пісні автора можна 3 упевненістю сказати, що найголовніше в їх написанні - це мелодика, яка вдало поєднується зі словом. Вразлива мелодійність, простота форми й вислову, вишуканість стилю написання й музичного смаку - все це відрізняє його від інших. Ком- 
позитор вважає, що після кропіткої роботи поєднаної $з$ неординарними музичними прийомами на світ народжуються справжні пісенні шедеври .

Ще на початку своєї творчої кар'єри він по-особливому хотів бачити пісню - в гарних витончених гармоніях i тонах, 3 красивими контрапунктами й акордами, а також із нестандартними, нехарактерними для класичної гармонії ходами. Безумовно, це згодом помічають і слухачі. Багато хто стверджує, що в його піснях наявні оригінальна мелодика, ідентична простота, теплота й щирість.

Цікавим $є$ те, що саме пошуки незабутньої мелодії надихнули автора на написання гімну для рідного міста. Слова цього гімну гордо наспівує кожен Сумчанин, адже він $є$ справжньою пісенною візитівкою нашого міста.

Недивно, що 3 кожним роком пісенний багаж поповнювався все новими й новими творами. Адже невимовна врода Сумчанок і нескінченні історії кохання кожного дня надихають автора. Творчість композитора спонукає до постійної динаміки почуттів. Наголосимо, що неповторні інтонації, які звучать у його піснях, наповнені яскравою самобутністю та самовираженістю.

Зазначимо, що його мелодії, немов безцінний діамант, прикрашають вірші видатних поетів. Це i Микола Гриценко, на слова якого був написаний гімн міста Суми, пісні «Сумщино моя», «Гімн Сумського земляцтва» й багато інших. Ціла низка романтичних пісень про кохання створені разом із геніальним поетом Олександром Вертілем. Чого варта тільки їх спільна пісня «Це наша свята перемога», яка присвячена нашому землякові, тричі герою Радянського Союзу I.M. Кожедубу, «Горобиновий романс», «Годинник любові». Важливим, як нам видається, є знайомства композитора 3 відомими на всю Україну поетами - Миколою Федоровичем Сингаївським та Заслуженим діячем України, президентом творчої спілки естрадних виконавців, поетом Віктором Володимировичем Герасимовим.

Закцентуємо на тому, що пісні Валерія Козупиці набули широкої популярності в Україні та далеко за їі межами. Авторські пісні композитора 3 радістю виконали зірки української естради Віталій і Світлана Білоножки, Лілія Сандулеса, Жанна Боднарук, ансамбль пісні і танцю Збройних сил України та дитячий академічний хор українського радіо та телебачення. Ціла низка пісень отримала нагороди на Всеукраїнських та міжнародних фестивалях «Пісня року», «Пісенний вернісаж», «Шлягер року», «Боромля», «Кролевецькі рушники».
Нині В. Козупиця працює солістом Сумської обласної філармонії. Постійні гастролі, записи в студіях звукозапису та виступи на концертних майданчиках різноманітних міст, районів і сіл $\epsilon$ невід'ємною частиною життя артиста сьогодні. «Нам завжди $є$ чим вразити глядача», - стверджує композитор. Він зауважував, що, гастролі мальовничою Україною, споглядання невимовної краси природи наших сіл, надихнули композитора на створення пісні «Здрастуй рідне село». Подарована одразу трьом виконавцям, вона заграла новими кольорами в різних аранжуваннях. Сьогодні ми чуємо цю пісню на українському радіо й телебаченні у виконанні «співучого» ректора - Михайла Поплавського, Івана Поповича та Віктора Шпортько.

У межах святкування ювілею Сумської області у 2019 році в будівлі Сумської обласної філармонії відбувся ювілейний сольний концерт Валерія Козупиці, присвячений рідному містові, який пройшов 3 аншлагом. Варто наголосити, що за свою активну творчу діяльність співака й композитора було нагороджено орденом 3 ступеня «За заслуги перед містом». У концерті брали участь Заслужений працівник культури України Євген Радченко, Заслужений артист України Леонід Матвієнко, Заслужений працівник культури України Тетяна Фінашко, а також солісти філармонії Ірина Ященко і Сергій Завгородній.

Кожногорокув місті Сумипроходитькультурномистецька акція «Мистецькі сходи». Зауважимо, що у 2019 році дана акція стала для В. Козупиці пам'ятною, оскільки йому вручено почесну відзнаку «Гордість культурно-мистецької Сумщини».

Ще одна постать, без якої не можна уявити Сумську обласну філармонію, - Заслужений артист України Леонід Матвієнко. Його по праву називають «Золотий голос Сумщини», «Наш Магомаєв».

Леонід Матвієнко народився 1950 року в селі Юнаківка на Сумщині. Має незакінчену середню спеціальну освіту. Стаж концертної діяльності 46 років. До того ж, він є Заслуженим артистом Абхазії (1984), Заслуженим артистом України (1999), учасником бойових дій в Афганістані.

3 раннього дитинства Л. Матвієнко розумів, що пісня - це його душа. Вперше вийшов на сцену 12-річним хлопчиком. Тоді в межах конкурсу прозвучала всім відома українська пісня «Вечір на дворі» в супроводі баяну, за виконання якої артист отримав другу премію. Закінчивши середню школу, вступив одразу на другий курс Сумського культурно-освітнього училища, іспити й заліки за який склав екстерном. 
Переконані, що баритон артиста розкривається по-новому з кожним концертним виступом. Його голос неможливо не впізнати. Надзвичайна сила голосу, харизма та красивий тембр голосу мають неабиякий вплив на слухача. Кожний його виступ - це шквал овацій від вдячного слухача. Зауважимо, що такий талановитий артист, якого знають, люблять і завжди раді бачити в будьякому куточку України, з великим задоволенням гастролює і дарує свою творчість не тільки в містах, але й невеличких селах, де дуже часто немає навіть сцени, але, як говорить митець, така вже доля артиста - співати не там, де хочеться, а там, де чекають і де слухатимуть.

Значний період життя Л. Матвієнка пов'язана 3 гастрольною діяльність в країни пострадянського та європейського простору. До того ж, з армійським хором артисту також довелося гастролювати Австралією.

Вважаємо за доцільне зазначити, що протягом усього життя Л. Матвієнко залишався вірним своїм артистичним уподобанням, ідеалам, смакам. Ще 3 ранньої молодості йому імпонували видатні українські виконавці: Дмитро Гнатюк та Анатолій Мокренко. А справжніми майстрами й ідеалами вокалу вважає Мусліма Магомаєва, Сергія Захарова та Лева Лещенка.

3 червня 2014 року працює в Сумській обласній філармонії. Щомісяця тільки на базі Сумської обласної філармонії він дає два сольних концерти. А ще райони, села, а також сусідні області - усе це наповнює щільний графік виступів артиста.

Леонід Матвієнко на пісенній сцені вже майже півстоліття, з яких половина - в Сумах. І творчість і невичерпний талант гідно оцінило керівництво міста. Він нагороджений знаком за заслуги перед містом Суми 3 ступеню. Також має численні грамоти від міських голів та міністрів оборони.

У його репертуарі: «Пісня про рушник», «Два кольори», «Осіннє золото», «Черемшина», російськомовні «Зимняя любовь», «Пока я помню, я живу», «Синяя вечность», «Ноктюрн» та ін. Проте, зауважимо, що артист залюбки включає до репертуару нові твори сучасних авторів. На окрему увагу, як нам видається, заслуговує концертна програма, яка називається «Тобі, єдиній» - за піснею поета Євгена Гущина на музику запорізького композитора заслуженого артиста України Анатолія Кобзаря.

У контексті статті вважаємо за необхідне наголосити, що протягом творчої діяльності Л. Матвієнко притримується принципу - неважливо в якому місті, залі та для якої кількості людей, я завжди буду «ввідаватись» на сцені сповна. Зна- чимим, як нам видається, $\epsilon$ те, що для молодих виконавців, колег по роботі він завжди $є$ і буде взірцем людяності, таланту, артистизму. Всі обласні і міські заходи проходять за участю цього артиста. Він жодного разу не пошкодував, що живе в слобожанському обласному центрі, а тим паче ніколи навіть і не намагався «осідлати» Київ. Давно збагнув, що столиця його пісенної душі - Суми, без яких йому не жити.

Мета дослідження вимагає звернути увагу ще на одну постать Сумської обласної філармонії безмежно талановитого співака, автора пісень і яскравого артиста - Заслуженого працівника культури України Євгена Радченка. Він народився 23 грудня 1962 року.

На нашу думку, Свгена Радченка можна вважати одним із найекстравагантніших артистів Сумщини. Співак, композитор, автор та виконавець багатьох пісень різної тематики: українські, патріотичні та звичайно особливе місце в його творчості посідають пісні про кохання.

3 2012-го - він соліст обласної філармонії. Євген Радченко зазначає, що в 1995 році, коли він був на концерті Валерія Леонтьєва в театрі ім. Щепкіна з Іваном Веснич, тоді вже колишнім гітаристом групи «Ехо», останній зауважив, що Євген дуже схожий на Кіркорова, і порадив цю подібність обіграти у своїх виступах. Загалом, із цього моменту й почався новий період у творчості Євгена Радченка, якщо можна так сказати, «кіркорівська» епоха. Раніше Свген Радченко був керівником київського рок-гурту «Академія», який грав хард-рок. Після його розпаду приїхав до Сум. У цей самий час у нашому місті побував із гастролями харківський театр двійників «Приват». Радченка прослухали й відразу ж взяли в колектив на роль двійника Кіркорова. Продюсер Альфред Страшинська був уражений не стільки портретною схожістю з Кіркоровим, скільки вокальними даними. Адже більшість двійників - просто копії тієї чи іншої зірки й відкривають рот під фонограму. Двійників, які співають, одиниці, до того ж, у Євгена Радченка з Філіпом Кіркоровим однаковий діапазон, те саме забарвлення. Хоча манера співу різна. У «Приват» потрапила ще одна сумська артистка театру ім. Щепкіна, яка була в той час дуже схожа на Софію Ротару. Крім Кіркорова й Ротару, в театрі були двійники Пугачової, Кузьміна, Джексона та ін. 3 театром Свген Радченко об'їздив практично весь СНД.

Євген Радченко зазначає, що його схожість із Філіпом Кіркоровим допомагала його кар'єрі артиста. Спочатку було захоплення, автографи, фотосесії, натовпи шанувальників, а потім почало 
набридати, іноді зачіпало, дратувало. У Філіпа було і $є$ чому повчитися, адже це один із кращих артистів. Крім зовнішньої схожості Свген Радченко та Філіп Кіркоров народилися в одному й тому самому місяці (квітні) з різницею у два дні (Свген - 28, а Філіп - 30) та кілька років. Багато спільного й у характерах: сентиментальність, запальність. В одному і тому самому році отримали звання. У 2009 році Філіп Кіркоров отримав звання народного артиста Російської федерації, а Євген Радченко - заслуженого працівника культури України. Доньки народилися з інтервалом у декілька місяців: у Філіпа Кіркорова - в листопаді 2011 року, а у Євгена Радченко у квітні 2012 року.

Іншою відомою мистецькою постаттю $\epsilon$ Володимир Іванович Прихожай, який народився 30 листопада 1954 року в Глинську Сумської області. Володимир Прихожай є Заслуженим діячем мистецтв України, композитором, піаністом, аранжувальником; одним 3 організаторів фестивалю «Sumy jazz fest».

Творчу діяльність Володимир Прихожай розпочав під час служби в ансамблі пісні й танцю Червонопрапорної Каспійської флотилії в місті Баку. Закінчив два курси Бакинської консерваторії по класу композиції. Працював у різних філармонійних колективах, зокрема, 3 Іриною Понаровською, Лолітою Мілявською. Випускник Харківської Академії мистецтв і культури (естрадно-джазове відділення). Учасник бага- тьох джаз фестивалів, починаючи 31986 року. Дипломант i лауреат міжнародних джазових фестивалів. Володимир Прихожай $\epsilon$ незмінним керівником інструментального ансамблю «АРАМІС» Сумської обласної філармонії.

Висновки. Підсумовуючи зазначене вище, можемо констатувати, що філармонійна діяльність Сумщини заслуговує на вивчення. У Сумській обласній філармонії працюють талановиті митці, серед яких В. Козупиця, Л. Матвієнко, В. Прихожай, Є. Радченко. Їх творчий доробок складають пісні різних жанрів.

Широкий вектор творчості регіональних митців вказує на їх плідну роботу у своїй галузі, i це засвідчують матеріали різного спрямування: 1) концертні афіші; 2) коментарі та відгуки, які залишають слухачі в соціальних мережах щодо виступу артиста; 3) документальні матеріали (звіти різноманітних обласних, районних концертних та мистецьких установ і товариств); 4) статті аналітичного характеру, які присвячені ювілейним датам виконавців i композиторів; 5) підсумкові звіти стосовно творчої діяльності культурно-мистецьких закладів та підсумкової роботи творчих колективів; 6) численні публікації регіональних видань, що засвідчують високу професійну майстерність і статусність артистів регіону; 7) відео звіти концертних виступів на різноманітних майданчиках; 8) ротація на радіо та телебаченні.

\section{СПИСОК ВИКОРИСТАНИХ ДЖЕРЕЛ}

1. Маестро Козупица. URL: http://www.golos.com.ua/rus/article/41439

2. «Панорама» (Сумы): До сих пор историки спорят о дате основания города. URL: http://arhiv.orthodoxy.org.ua/ $\mathrm{ru} / 2007 / 10 / 22 / 10993 . \mathrm{html}$

3. Прихожай Владимир. URL: http://uajazz.com/2008/01/prikhojay/

4. Сайт Сумської обласної філармоніï. URL: https://filarmoniya.sumy.ua/

5. Симоненко В. С. Прихожай Володимир Іванович. Українська енциклопедія джазу. Київ: Центрмузінформ, 2004. C. 92.

\section{REFERENCES}

1. Maestro Kozupytsa [Maestro Kozupitsa]. URL: http://www.golos.com.ua/rus/article/41439 [in Russian].

2. Panorama» (Sumy): Do sykh por ystoryky sporiat o date osnovanyia horoda [«Panorama» (Sumy): Until now, historians argue about the date of the city's foundation]. URL: http://arhiv.orthodoxy.org.ua/ru/2007/10/22/10993.html [in Russian].

3. Prykhozhai Vladymyr [Prikhozhai Vladimir]. URL: http://uajazz.com/2008/01/prikhojay/ [in Russian].

4. Sait Sumskoi oblasnoi filarmonii [Website of the Sumy Regional Philharmonic]. URL: https://filarmoniya.sumy.ua/ [in Ukrainian].

5. Symonenko V. S. (2004). Prykhozhai Volodymyr Ivanovych. Ukrainska entsyklopediia dzhazu [Prykhozhai Volodymyr Ivanovych]. Kyiv: Tsentrmuzinform. S. 92 [in Ukrainian]. 